\title{
Minat Belajar Matematika dengan Memanfaatkan Budaya Lokal di Desa Silo Lama
}

\author{
Ainul Marhamah Hasibuan*1, Syahrina Anisa Pulungan² \\ 1,2Dosen Pendidikan Matematika STKIP Amal Bakti Medan, Indonesia \\ *e-mail: ainulmarhamahhsb@gmail.com ${ }^{1}$, syahrinaanisa7@gmail.com ${ }^{2}$
}

\begin{abstract}
Abstrak
Dalam kegiatan pengabdian masyarakat ini, peneliti melakukan sebuah penyuluhan penelitian tentang minat belajar matematika dengan memanfaatkan Budaya Lokal. Penelitian ini bertujuan untuk meningkatkan minat belajar matematika siswa dengan memanfaatkan budaya local. Hasil penelitian menunjukkan bahwa berdasarkan data yang ditunjukkan oleh hasil angket, wawancara atau observasi selama proses pembelajaran berlangsung, rata-rata hasil angket minat belajar sebelum tindakan adalah 63,07\%, setelah siklus I adalah 65,70\% dan setelah siklus II adalah 76,48\% (tinggi) artinya ada peningkatan minat belajar dari prabelajar ke siklus I sebesar 7,33\% dan dari siklus I ke siklus II sebesar 7,08\%. Untuk rata-rata hasil observasi minat belajar pra penelitian adalah 34. 54\% pada siklus I adalah 54,43\% dan siklus II adalah 71,21\% Dari pra penelitian ke siklus I terjadi peningkatan sebesar 14,46\%, dari siklus I ke siklus II naik 18,41\%. Secara keseluruhan dari pra penelitian sampai akhir penelitian terjadi peningkatan sebesar 33,57\%. Hal ini menunjukkan bahwa dengan memanfaatkan Budaya Lokal siswa menjadi lebih bersemangat untuk belajar matematika.
\end{abstract}

Kata kunci: budaya lokal , matematika, minat belajar

\begin{abstract}
In this community service activity, the researcher conducted a research counseling about interest in learning mathematics by utilizing local culture. This study aims to increase students' interest in learning mathematics by utilizing local culture. The results showed that based on the data shown by the results of questionnaires, interviews or observations during the learning process, the average result of the questionnaire on interest in learning before the action was $63.07 \%$, after the first cycle was $65.70 \%$ and after the second cycle was 76, 48\% (high) means that there is an increase in interest in learning from pre-learning to cycle I by $7.33 \%$ and from cycle I to cycle II by 7.08\%. For the average observation result of pre-study learning interest is $34.54 \%$ in the first cycle is $54.43 \%$ and the second cycle is $71.21 \%$ From pre-research to cycle I an increase of $14.46 \%$, from cycle I to cycle II rose $18.41 \%$. Overall, from pre-study to the end of the study, there was an increase of 33.57\%. This shows that by utilizing Local Culture students become more enthusiastic about learning mathematics.
\end{abstract}

Keywords: interest in learning, local culture, mathematic

\section{PENDAHULUAN}

Pendidikan merupakan hal yang tidak dapat dipisahkan dari kehidupan manusia. Pendidikan dapat dijadikan sebagai tolak ukur kemajuan bangsa. Bangsa yang maju adalah bangsa yang memiliki sumber daya manusia yang berkualitas, baik dari segi spiritual, kecerdasan maupun keterampilan. Salah satu cara yang dapat dilakukan untuk mencapai tujuan tersebut adalah pembaharuan secara terus menerus dalam bidang pendidikan khususnya matematika [1].

Salah satu diantara masalah dalam bidang pendidikan yang banyak diperbincangkan adalah rendahnya mutu pendidikan yang tercermin dari rendahnya rata-rata prestasi belajar. Masalah lain dalam pendidikan juga yang banyak diperbincangkan adalah bahwa pendekatan dalam pembelajaran masih terlalu didominasi peran guru (teacher center). Pendidikan kita kurang memberikan kesempatan pada siswa dalam berbagai mata pelajaran untuk mengembangkan kemampuan berpikir holistik (menyeluruh), kreatif, objektif, dan logis. Belajar dan mengajar merupakan dua konsep yang tidak bisa dipisahkan satu sama lain. Jadi belajar mengajar merupakan proses interaksi antara guru dan siswa pada saat proses pengajaran. Proses pengajaran akan berhasil, selain ditentukan oleh kemampuan guru dalam menentukan 
metode dan alat yang digunakan dalam pengajaran, juga ditentukan oleh minat belajar siswa.

Minat belajar merupakan salah satu pengaruh besar terhadap aktivitas belajar.proses belajar akan berjalan lancer bila disertai dengan minat. Minat merupakan alat motivasi yang utama yang dapat meningkatkan belajar siswa agar pelajaran yang diberikan mudah diterima dan dipahami. Ada beberapa cara yang dapat dilakukan untuk membangkitkan minat belajar siswa sebagai berikut [2]: a. Membandingkan adanya suatu kebutuhan pada diri siswa, sehingga dia rela belajar tanpa paksaan. b. Menghubungkan bahan pelajaran yang diberikan, dengan persoalan pengalaman yang dimiliki siswa, sehingga siswa mudah menerima bahan pelajaran. c. Memberikan kesempatan kepada siswa untuk mendapatkan hasil belajar yang baik dengan cara menyediakan lingkungan belajar yang kreatif dan kondosif. d. Menggunakan berbagai macam bentuk dan teknik mengajar dalam konteks perbedaan individual siswa.

Minat adalah kecenderungan yang tetap untuk memperhatikan dan mengenang beberapa kegiatan [3]. Sedangkan menurut pendapat ahli lainnya "minat adalah rasa lebih suka dan rasa ketertarikan pada suatu hal atau aktivitas, tanpa ada yang menyuruh [4]. Sedangkan menurut Crow\&crow [5] mengatakan bahwa "minat berhubungan dengan gaya gerak yang mendorong seseorang untuk menghadapi atau berurusan dengan orang, benda, kegiatan, pengalaman yang dirangsang oleh kegiatan itu sendiri". Dari beberapa pendapat para ahli diatas dapat disimpulkan bahwa pengertian minat adalah rasa ketertarikan, perhatian, keinginan lebih yang dimiliki seseorang terhadap suatu hal, tanpa ada dorongan.

Minat belajar merupakan faktor yang sangat berpengaruh dalam kegiatan belajar mengajar. Dengan adanya minat belajar siswa dapat memberikan perhatian lebih dalam pembelajaran matematika. Melihat minat belajar menjadi salah satu faktor penentu yang dapat mempengaruhi pencapaian hasil belajar, maka peningkatan minat belajar dinilai harus dilakukan. Pembelajaran matematika yang membutuhkan minat belajar yang cukup tinggi adalah pembelajaran matematika. Matematika menjadi mata pelajaran yang ditakuti oleh siswa, sehingga minat belajar matematika siswa kurang. Hal ini mengakibatkan kepada pencapaian belajar siswa yang kurang baik. Melihat pencapaian belajar siswa yang kurang baik karena tidak adanya minat belajar siswa pada matematika. Hal ini mendorong keingintahuan terhadap faktor, jenis, serta ciri - ciri minat siswa pada saat belajar matematika. Maka tujuan dari penulisan artikel ini untuk mengkaji faktor, jenis, serta ciri - ciri minat belajar siswa pada matematika.

\section{METODE}

Dalam pelaksanaan kegiatan pengabdian ini, Tim memanfaatkan fasilitas yang ada. Tim pelaksana memilih pelatihan sebagai metode dalam pelaksanaan kegiatan pengabdian ini. Adapun tahapan-tahapan dalam pelaksanaan pelatihan ini disesuaikan dengan solusi yang diharapkan mitra, yaitu: Kebutuhan untuk meningkatan kompetensi guru dalam mengelola pembelajaran dengan memanfaatkan budaya local dengan baik. Pelatihan ini dilaksanakan guna meningkatkan kompetensi siswa dalam meningkatkan minat belajar matematika dengan memanfaatkan budaya local.

Metode yang dilakukan adalah dengan wawancara dan observasi. Dimana wawancara dan observasi ini dilakukan sejalan, karena ketika melakukan observassi sekolah kemudian dilaksanakan dengan wawancara. Wawancara kepada kepala sekolah dan guru-guru bahwa mina belajar siswa terhadap matematika masih tergolong kurang, karena mereka berasumsi bahwa belajara matematika membuat pusing mereka. Hasil observasi yang didapat bahwa sarana dan prasarana masih kurang. Maka dari itu penelitian ini ingin meningkatkan minat belajar siswa dnegan menggunakan budaya local.

\section{HASIL DAN PEMBAHASAN}

Tim pelaksana pengabdian STKIP Amal Bakti melaksanakan kegiatan pengabdian pada hakikatnya merupakan bentuk dukungan kampus. Karena itu, tim pelaksana pengabdian kepada masyarakat fokus untuk mencarikan solusi terhadap permasalahan yang ada. Hasil kegiatan 
pengabdian kepada masyarakat dapat dilihat dalam kegiatan-kegiatan yang dilaksanakan tim pelaksana.

Pertama, melaksanakan pelatihan bagi guru-guru SD Silo Lama. Dalam pelatihan ini guru-guru dilatih dalam pembuatan rencana pembelajaran praktis, pembuatan bahan ajar, dan metode penilaian hasil belajar. Dalam kegiatan ini selain memberikan pengetahuan dan teknik pengelolaan pembelajaran, tim pelaksana pengabdian masyarakat juga memeberikan pemahaman terhadap guru-guru dan siswa tentang pentingnya keterbukaan hati dan kesadaran untuk menerima keadaan. Tujuannya adalah sikap terbuka dan menerima serta kemampuan beradaptasi terhadap perubahan tersebut menjadi spirit untuk melakukan hal-hal yang positif guna mendukung akivitas yang dibutuhkan dalam meningkatkan kinerja individu.

Kemudian daripada itu, dalam pelatihan ini guru-guru juga dilatih dalam menyusun rencana program pembelajaran ringkas satu halaman, pembuatan bahan ajar, metode pembelajaran di masa pandemi, dan penilaian hasil atau capaian belajar peserta didik. Rencana program pembelajaran atau rencana pelaksanaan pembelajaran (RPP) satu halaman merupakan kebijakan Kementerian dan Kebudayaan Republik Indonesia. Menteri Pendidikan dan Kebudayaan Republik Indonesia mengeluarkan surat edaran Nomor 14 Tahun 2019 tentang Penyederhanaan Rencana Pelaksanaan Pembelajaran.

Dalam kegiatan pelatihan tim pelaksana pengabdian menitikberatkan pada kemapuan menyusun bahan ajar, metode, dan penilaian hasil belajar. Guru- guru mempersiapkan bahan ajar dalam pembelajaran. Untuk pembelajaran yang efektif dan efisien oleh guru selama pembelajaran Bahan ajar dan metode yang tepat. Hal lain yang tidak boleh diabaikan adalah penilaian hasil pembelajaran. Dalam melakukan penilaian hendaknya guru berfokus pada penguasaan sikap, keterampilan, dan pengetahuan secara utuh dari peserta didik serta memegang prinsip kesinambungan, komprehensif, objektivitas, dan mengacu pada tujuan[4].

Pada Gambar 1 dan Gambar 2 di bawah adalah, dimana proses pembelajaran siswa dengan menggunakan budaya local pada materi pecahan.

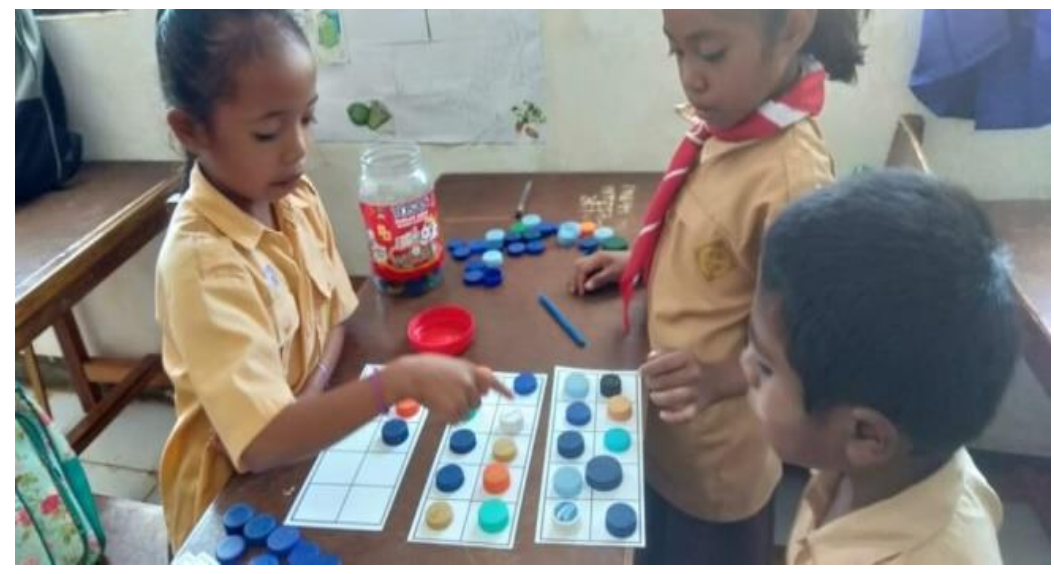

Gambar 1. Siswa Menggunakan Tutup Botol

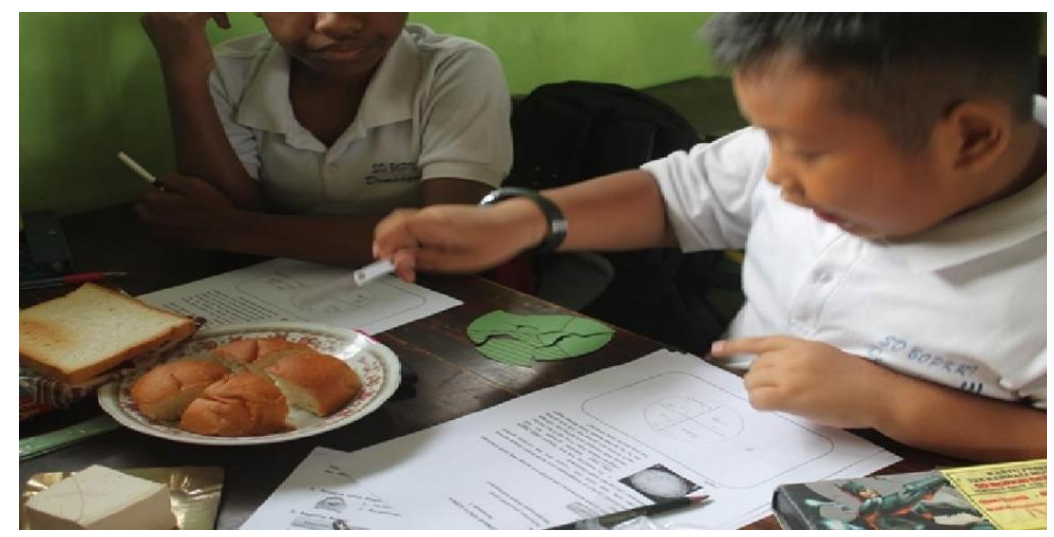

Gambar 2. Siswa menggunakan Roti 


\section{KESIMPULAN}

Berdasarkan pelaksanaan kegiatan pengabdian masyarakat oleh peneliti di SD Silo Lama: (a) Guru-guru SD Silo Lama memiliki kemampuan beradaptasi dengan baik dengan memiliki kemampuan dalam mendisain baik.

Sebagai tindak lanjut kegiatan pengabdian masyarakat ini, diharapkan kepada pemangku kebijakan dan lembaga terkait untuk ambil bagian dalam melakukan kegiatan pendampingan dan dukungan terhadap guru-guru dan siswa dalam mengelola pembelajaran sekaligus melakukan monitoring dan evaluasi terhadap proses pembelajaran. Kemudian peningkatan minat belajar siswa lebih baik dengan memanfaatkan budaya lokal

\section{UCAPAN TERIMA KASIH}

Tim pelaksana pengabdian masyarakat mengucapkan terimakasih kepada STKIP Amal Bakti yang telah memberikan dukungan.

\section{DAFTAR PUSTAKA}

[1] A. M Hasibuan, S. Saragih, Z. Amry, "Development of Learning Materials Based on Realistic Mathematics Education to Improve Problem Solving Ability and Student Learning Independence," IJME. e-ISSN: 1306-3030. 2019, Vol. 14, No. 1, 243-252,2019, https://doi.org/10.29333/iejme/4000.

[2] S. B. Djamarah, Strategi Belajar Mengajar. Jakarta: Rineke Citra, 2011.

[3] Slameto, Belajar dan Faktor-faktor yang mempengaruhinya. Jakarta: Rineka Cipta, 2016.

[4] Djaali, Psikologi Pendidikan. Jakarta: Bumi Aksara, 2013.

[5] S. Suhendri, "Evaluasi Pendidikan Dalam Perspektif Filsafat Pendidikan Islam. Almufida: Jurnal Ilmu-Ilmu Keislaman", 3(1), 29-43, 2018. http://jurnal.dharmawangsa.ac.id/index.php/almufida/article/view/92. 